\title{
THEORETICAL APPROACHES ON CORPORATE SOCIAL RESPONSIBILITY
}

\author{
Leontin STANCIU, Cristian-Lucian STANCIU \\ "Nicolae Bălcescu" Land Forces Academy Sibiu, Romania \\ leontinstanciu@yahoo.com, stanciu_cristian_ro@yahoo.com
}

\begin{abstract}
Under the conditions of a knowledge-based economy, maximizing the value of the economic entities cannot be achieved solely by basic activities. Fulfilling this fundamental objective implies carrying out other types of activities with a social impact unified under the concept of social responsibility. In this context, the authors aim to empirically investigate this concept both in terms of its evolution and the way it is implemented in the national economies and in the local communities.
\end{abstract}

Keywords: economic globalization, corporate social responsibility, economic entities, local communities

\section{Introduction}

Taking into account the economic globalization, the competitiveness of the economic organizations is influenced, to a great extent, by the ability of their managers to develop an integrative vision of the ways of interpreting the socio-economic phenomena and processes.

In the current context, the economic organizations are no longer evaluated solely according to product quality, but also according to their contribution to the lives of the communities they are part of.

At international level, an increasing number of economic entities have become aware of the need and the benefits of engaging in the life of the communities. The United Nations initiative has laid the foundation for the necessary framework to stimulate the economic organizations to have a proactive attitude towards social responsibility. The Organization for Economic Cooperation and Development (OECD) has also developed the basic principles of social responsibility for the multinational companies. The European Commission has created the formal framework required for the development and the specific corporate social responsibility objectives.

Lately, a significant percentage of the companies' budgets has been assigned to the social responsibility in order to meet the medium and long-term strategic objectives in terms of community support and sustainable development.

In view of the above, we consider that it is required to conduct a more thorough study of the social responsibility, which has recently been practiced by a wider number of economic organizations in Romania.

\section{The Content and the Evolution of the Corporate Social Responsibility (CSR) Concept}

The first debates on the concept of Corporate Social Responsibility (CSR) took place in the early 1950s in the academic environment.

Initially promoted under the name of "social responsibility", the concept highlighted in particular the expectations of the communities from the business environment 
and the ethical obligations of the companies towards them. Thus, Howard Bower, considered to be the "father" of CSR, defined the concept as "the businessmen's obligations to pursue those policies, to make those decisions, or to follow those directions that are agreed in terms of values and objectives by our society "[1]

The businessmen's responsibility prevailed until the 70s, while subsequently the emphasis was laid on the social responsibility of the economic organizations. Thus, H.L. Johnson argues that a company should not only seek to maximize its profit, but also the interests of its employees, suppliers, communities and society. [2]

An important contribution to clarifying the concept of corporate social responsibility was that of A. B Caroll who claims that CSR is made up of four key pillars which are: economic, legal, ethic and philanthropic. By calling them "the pyramid of the corporate social responsibility," the four key pillars of CSR are explained as follows:

- economic - it highlights the responsibility of the economic organizations to maximize their profit from the production of goods and services needed by the society;

- legal - it highlights the responsibility of the management of the economic organizations to obey the regulatory framework;

- $\quad$ etic - it highlights "the behavior" and the responsibility of the companies to comply with the social norms uncoded by laws but expected by "the actors" operating in the society;

- philanthropic - it highlights the voluntary involvement of the economic organizations in helping the community they belong to. [3].

The European Union defines social responsibility as a concept through which an economic organization voluntarily integrates its concerns about social and environmental issues into their business operations and it the interaction with the stakeholders.

Worldwide, the debate on the concept of corporate social responsibility coincided with the one on sustainable development, an issue expressed by the UN in 1992 at the international Summit in Rio. Until 2000, the sustainable development was a topic addressed in macroeconomic terms, while at present it is mainly debated in microeconomic terms at the level of the economic entities, especially the multinational companies. Therefore, at the microeconomic level, the sustainable development materialized in the concept of corporate social responsibility. In the "Green Paper", the European Commission defined this concept as the companies' voluntary integration of social and environmental problems of the communities in which they operate in their economic activity and in their relation with the interest groups. Practically, from this definition, we can identify three aspects that are characteristic of corporate social responsibility, namely:

- is a voluntary action of the economic entities;

- it implies a three-dimensional approach: from an economic, social and environmental point of view;

- it reports to the interest groups of the economic entities ("the stakeholders")

\section{Main Categories of Corporate Social Responsibilities}

There are three main categories of corporate social responsibilities in the literature, namely:

a) the social obligation;

b) the social reaction;

c) the social sensitivity. [4]

a) As social obligation, the corporate responsibility is supported by the following arguments:

- the first argument - the management of an economic entity has the major 
responsibility to maximize the wealth of the shareholders;

- the second argument - the activities with a social impact (the social programs) must be regulated by law, by public policies and by private actions/contributions; in this context, the economic entities contribute to the financial support of these activities by paying taxes;

- the third argument- by allocating some amount from the obtained proceeds to support activities with a social impact, the management of the economic entity affects the interests of its owners as it takes over a part of their income; at the same time, financing non-profit activities is not an action desired by the owners/shareholders;

- the fourth argument - over time, the costs of activities/actions with a social impact may generate an increase of the prices of the goods marketed by the entity and their consumers will ultimately pay the bill of the social efforts made by the entity.

b) Social reaction is another form of manifestation of the social responsibility, being generated by the fact that society as a whole needs to receive more from the economic entities than their goods and services. In practice, an economic entity must be responsible for the environmental and social costs it implies, and on the other hand it must contribute to solving the community's problems, including those that cannot be attributed to it.

Social responsibility, as a social reaction, requires only voluntary action conducted by the economic entities.

Keith Davis, a management specialist, claims that an economic entity is not socially responsible when it confines itself to meeting the social requirements stipulated by the legislation in force. [5] Actually, corporate social responsibility means more than that. c) Social sensitivity involves a socially responsible and preventive social behavior, materialized in:

- helping resolve social issues (providing scholarships to youth in local schools, helping to start small businesses within the community in order to create jobs in the area, etc.)

- anticipating the future needs of the community and proactively getting involved in meeting them;

- creating and maintaining constructive communication with the public authorities; - promoting legislative initiatives to improve the legal framework with significant social impact, and so on.

\section{Beneficiaries of Corporate Social Responsibility}

In order to achieve socially responsible actions, the economic entities need to precisely identify their beneficiaries. In the practice of corporate social responsibility, there are two main categories of beneficiaries, namely internal and external:

a) Internal beneficiaries: - the clients, the employees, and the equity owners have immediate, divergent and sometimes conflicting interests.

In relation to the clients, the responsibilities of an economic entity derive from the social obligations depending on the characteristics of its products (quality, safety, packaging, etc.).

In relation to the employees, the responsibilities of the entity are, first of all, those stipulated by labor law. In addition to the legal responsibilities, the entity may extend the scope of the social impact activities by granting a number of benefits to its own employees (such as health, hospitalization or accident insurance, supplementary pension funds, etc.)

In relation to the equity owners, the responsibility of the entity's management is to show its shareholders correctly and 
completely how the resources and the results were used.

b) External beneficiaries may be specific and common. Both categories benefit, directly or indirectly, from the effects of the socially impacting actions conducted by the economic entities.

Modern society includes a wide variety of groups with specific interests (national minorities, elderly people, women, youth, the unemployed, etc.) and their main objective is to eliminate all discrimination. Foundations, government institutions, professional organizations and associations, as well as economic entities act in support of these specific beneficiary groups. The economic entities perform mandatory, reactive or affective actions.

The programs assigned for common external beneficiaries are a way of effectively implementing social responsibility, by which the economic entities contribute to preventing or solving social problems of the communities within which they conduct their activity.

\section{European Experiences in the Field of CSR}

The United Nations, the European Union and the Organization for Economic Cooperation and Development have been actively involved in developing both the necessary framework for desirable corporate behavior and the indicators by which it can be assessed transparently. As shown in the figure below, the corporate social responsibility framework includes recommendations and principles that the states and the local authorities should take into account when developing public policies in support of the CSR initiatives.

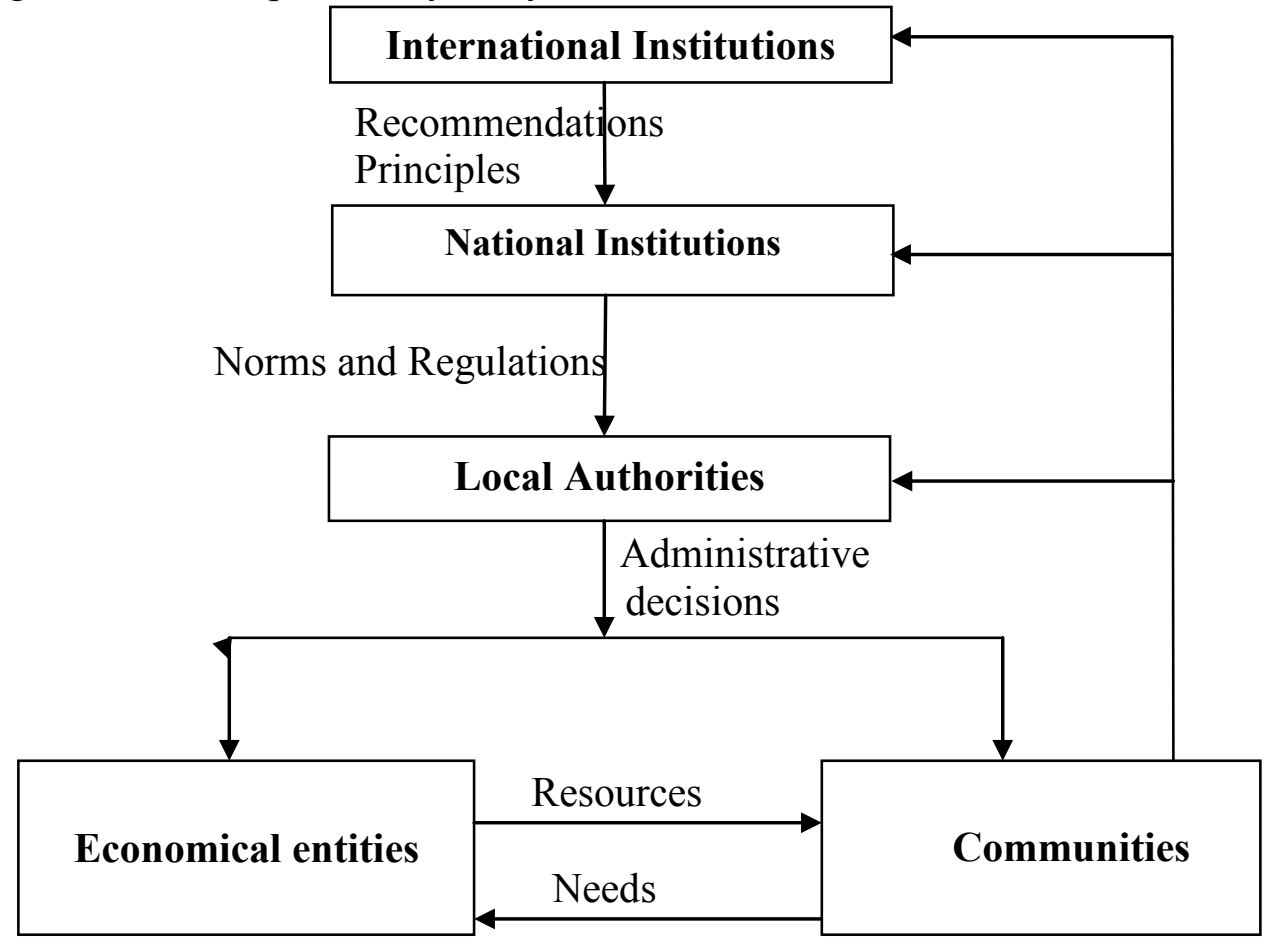

Figure no.1 CSR Framework

(Source: www.responsabilitatesocială.ro)

The European Union is interested in the economic entities' implementing CSR because it believes that the corporate social responsibility can contribute to fulfilling the 
goal set by the Lisbon European Council in 2000 to become the most competitive and dynamic economic system in the world. [6] Thus, in the EU vision of CSR, the economic entities have a number of social responsibilities such as:

\section{a) in the relationship with their own employees:}

- to permanently improve the employees' quality of life, both at work and outside the workplace;

- to ensure a healthy and safe working environment;

- to responsibly address restructuring, taking into account the interests of all the parties involved;

- to minimize the effects of their own activities on the environment and the natural resources;

b) the relationship with the communities in which they operate:

- to support their development;

- to promote the development of the local economic systems through partnerships with local distributors;

- to protect and encourage safeguarding the natural environment. [7].

Great Britain and Ireland are successful examples of integrating social responsibility into the business environment. [8] Thus, the UK occupies the second place in terms of social responsibility worldwide, after Japan. Ireland, with an economy mainly based on foreign investment, has managed to persuade companies to adopt a socially responsible behavior.

In the United Kingdom, the debate about corporate social responsibility began in the 1990s and included the business environment, the academia, the nongovernmental organizations, and so on. The British Government regards social responsibility as "a contribution of the business environment to achieving sustainable development goals. Social responsibility is the way in which businesses take into account the impact of their economic, social and environmental operations so as to maximize benefits and minimize negative impacts."[9]

The British Government also believes that social responsibility activities are voluntary actions conducted by companies. Promoting CSR among companies and state authorities is done by the Ministry of Social Responsibility, which operates within the British Government's Department of Trade and Industry.

An extremely important role in promoting social responsibility among British companies is played by the nongovernmental organizations such as Amnesty International, Christian Aid, Friends of the Earth, and others. The public reports of these organizations are of major interest to the British public opinion.

A major concern at the level of the United Kingdom is to stimulate SMEs to promote social responsibility in the communities in which they operate. These economic entities account for $99 \%$ of UK companies, and $60 \%$ of the country's working population is working within.

Ireland's industrial success is based on foreign investment. The industry contributes only one-third to the country's GDP, the construction sector being the most developed. [10] In this context, the Irish authorities argue that the promotion and development of social responsibility must be done voluntarily by the economic entities.

Regarding the significance and the integration of the social responsibility in the activity of the Irish companies, a study carried out in 2007 on a sample of 150 economic entities highlighted the following aspects:

- $70 \%$ of them invested in social responsibility, and $40 \%$ had been investing in this field for over 2 years; 
- the investment in social responsibility would be the first one diminished when spending cuts are to be made;

- in their view, social responsibility is predominantly, about $92 \%$, resumed to charitable activities;

- concerning the contribution of the socially impacting activities to increasing profitability; $56 \%$ of the respondents said that social responsibility contributed to the companies' profits. [11]

In Romania, corporate social responsibility has become an effective reality since the 2000 s, and a major factor in its emergence was the increase in the number of the multinational companies. Practically, these economic entities have transferred the organizational culture to the local communities where they operate. Initially the corporate social responsibility in Romania was valued, in particular, for its commercial attributes rather than for its ethical ones. Subsequently, activating in a competitive economic environment, more and more entities valued the role of CSR in the process of building and consolidating their own image and their reputation in the medium and long term. Social responsibility is not only a tool for valuing companies through image construction, but also a guarantee of long-term success, directly linked to the social and environmental performance of the local communities. [12] In Romania, CSR is promoted through various strategies developed by the multinational companies globally, sometimes tailored to the specific of the local communities but without a consistent creative component. Thus, the main standard CSR programs aim at:

- supporting social assistance activities; - making donations to local communities;

- sponsoring activities/actions with social impact;

- financing scientific research projects, educational and environmental programs, etc.
According to the study, "CSR Trends and Realities in Romania", conducted by CSRMedia.ro and Ernst\&Young Romania, corporate social responsibility increasingly borrows from the globally specific dynamism, the management of the Romanian companies understanding its role both in maximizing their value and in achieving sustainable local development. Thus, $78 \%$ of respondents stated that the entity they represent had a CSR dedicated strategy, and $67 \%$ of them believe that the general interest for CSR has increased over the past 12 months. Also, over $75 \%$ of the respondents said they had an annual budget assigned to CSR actions. [13]

Over time, a number of specific CSR programs have been developed by companies such as: Enel Romania, OMV, Orange Romania, Petrom, Coca-Cola HBC Romania, Romgaz, Unilever Romania, Dacia Groupe Renault, BCR, BRD-Groupe Societe Generale, Danone Romania, and others.

\section{Conclusions}

Under the current economic conditions, we consider that the economic entities, in order to maximize their value, should not be limited to their basic activity. Through global practices and strategies, through the consistent promotion of social responsibility projects, the value and the reputation of the economic entities will increase considerably. In a knowledge-based economy, corporate social responsibility is interdependent with knowledge management.[14] These are no longer attributes of the economic entities, but also basic conditions of an open effective market. We also assert that by promoting social responsibility, the economic entities contribute to the sustainable development of the communities and of the society as a whole, and all parties involved stand to gain. 


\section{References}

[1] Bowen, H., Toward Social Responsibilities of the Businessman, New York: Harper and Row, 1953.

[2] Stancu, A., Marketing și responsabilitate socială, Bucharest, ASE Publishing House, 2012, pp.27-28.

[3] Burton, B., Goldsbey M., Corporate Social Responsibility Orientation, Goals and Behavior: A study of Small Business Owners, Business and Society, vol.48;88; 2009, pp.89, SAGE.

[4] Militaru, Gh., Comportament organizațional, Bucharest, Economic Publishing House, 2005, pp. 148 .

[5] Keith, D., The Case for and against Business Assumption of Social Responsibilities, Academy of Management Journal, June 1973, pp.313

[6] Lisbon European Council, 23-24 March 2000, Presidency Conclusions, available at http://www.europarl.europa.eu/summits

[7] www.responsabilitatesocială.ro

[8] Stancu, A., op.cit, pp.54-55.

[9] CSR Ministery, What is CSR?, available at http://www.csr.gov.uk/whatiscsr.html.

[10] Stancu, A., op.cit, pp.65.

[11] Tyrell, A., Corporate Social Responsibility in Ireland, available at http://bccc.net

[12] Diniță, Al., Responsabilitatea corporativă în România-de unde și încotro?, available at www.responsabilitateasocială.ro/editoriale.

[13] CSRMedia, Primul studio despre Responsabilitatea Corporativă în România ca instrument strategic, available at http://www.csrmedia.ro

[14] Hristea, A.M, Responsabilitaea socială corporativă-între deziderat și realitate, in "Economia teoretică și aplicată” Magazine, vol. XVIII (2011), No.10 (563), pp.73 